RETHINKING JUVENILE JUSTICE 



\section{RETHINKING \\ JUVENILE JUSTICE}

ELIZABETH S. SCOTT • LAURENCE STEINBERG

Harvard University Press

Cambridge, Massachusetts

London, England

2008 
Copyright (C) 2008 by the President and Fellows of Harvard College

All rights reserved

Printed in the United States of America

Library of Congress Cataloging-in-Publication Data

Scott, Elizabeth S., 1945-

Rethinking juvenile justice / Elizabeth S. Scott and Laurence

Steinberg.

p. $\mathrm{cm}$.

Includes bibliographical references and index.

ISBN-13: 978-0-674-03086-2 (alk. paper)

1. Juvenile justice, Administration of-United States.

I. Steinberg, Laurence D., 1952- II. Title.

KF9779.S36 2008

345.73'08—dc22 2008005133 